\title{
HUBUNGAN PENDAPATAN ASLI DAERAH (PAD) DAN DANA ALOKASI UMUM (DAU) DENGAN BELANJA MODAL PADA PEMERINTAH DAERAH SE-PROVINSI JAWA BARAT
}

\author{
Rully Dea Clara RM \\ Heni Mulyani
}

\begin{abstract}
ABSTRAK
Penelitian ini bertujuan untuk mengetahui bagaimana hubungan pendapatan asli daerah dan dana alokasi umum dengan belanja modal pada pemerintah daerah se-provinsi Jawa Barat tahun anggaran 2012. Dalam rangka pelaksanaan otonomi daerah, belanja modal dilakukan oleh pemerintah daerah untuk pengadaan asset sebagai investasi yang bertujuan untuk meningkatkan pelayanan dan kesejahteraan publik. Faktanya, hal ini belum tercapai sepenuhnya apabila melihat alokasi belanja modal yang relatif belum terlalu tinggi dibandingkan dengan belanja lainnya, padahal semakin banyak belanja modal berupa infrastruktur tentunya akan berdampak pada pertumbuhan ekonomi daerah.

Metode yang digunakan pada penelitian ini adalah metode deskriptif verifikatif. Populasi dan sampel pada penelitian ini adalah 26 Kabupaten/Kota di Jawa Barat. Pengujian statistik yang digunakan adalah analisis korelasi multiple dengan uji $\mathrm{F}$ dan uji $\mathrm{t}$ pada taraf signifikansi 5\%. Perhitungan statistik tersebut dibantu software SPSS V.20 for windows dan Microsoft Excel 2010.

Hasil penelitian menunjukkan bahwa PAD memiliki hubungan positif yang sangat kuat dengan belanja modal sebesar 0,9013. Begitu pula dengan DAU memiliki hubungan positif yang sedang dengan belanja modal sebesar 0,5898. Selain itu, dengan menggunakan korelasi multiple didapatkan hasil bahwa PAD dan DAU memiliki hubungan positif yang sangat kuat dengan belanja modal sebesar 0,9413.
\end{abstract}

Kata Kunci : Pendapatan Asli Daerah (PAD), Dana Alokasi Umum (DAU), Belanja Modal, Keuangan Daerah.

\section{Pendahuluan}

Pemerintah Daerah (pemda) harus mampu mengalokasikan belanja modal dengan baik karena belanja modal merupakan salah satu langkah bagi pemerintah daerah untuk memberikan pelayanan kepada publik.

Peningkatan investasi modal dalam bentuk aset tetap, yakni peralatan, bangunan, infrastruktur, dan harta tetap lainnya diharapkan mampu meningkatkan kualitas layanan publik, karena aset tetap yang dimiliki sebagai akibat adanya belanja modal merupakan prasyarat utama dalam memberikan pelayanan publik oleh pemerintah daerah. Dengan adanya pelayanan publik yang baik, akan mendorong investor untuk menanamkan modalnya di daerah, yang nantinya akan berdampak pada meningkatnya pendapatan asli daerah.

Namun, fakta yang terjadi saat ini adalah pemerintah daerah lebih banyak mengalokasikan pendapatan yang diperoleh untuk membiayai belanja rutin atau belanja operasi daripada belanja modal. Padahal seperti yang telah dijelaskan sebelumnya, belanja modal diharapkan akan menambah daya tarik investor untuk berinvestasi di daerah tersebut, menambah pendapatan asli daerah yang akhirnya akan mengurangi ketergantungan pemerintah daerah terhadap pemerintah pusat sehingga kemandirian daerah tercapai.

Persentase belanja pegawai, belanja barang dan jasa, serta belanja lainnya (belanja rutin) di seluruh provinsi di Indonesia meningkat setiap tahunnnya dengan nilai yang relatif konstan. Hal ini berbanding terbalik dengan Belanja Modal yang mengalami penurunan sekitar $8 \%$ dalam kurun waktu 5 tahun terakhir.

Komponen yang memiliki proporsi terbesar dalam belanja rutin adalah belanja pegawai. Belanja pegawai merupakan belanja yang dipergunakan unuk membayar gaji pegawai pemerintah, 
atau lebih dikenal dengan Pegawai Negeri Sipil. Dalam hal ini, belanja pegawai dipandang sebagai belanja tetap, dimana jumlahnya kemungkinan besar tidak dapat dikurangi karena pemerintah tidak dapat mengurangi jumlah PNS melalui mekanisme Pemutusan Hubungan Kerja (PHK) sebagaimana yang dilakukan oleh pihak swasta. Jumlah PNS akan berkurang dengan mekanisme pensiun. Oleh karena itu, pemerintah, termasuk pemerintah daerah, sangat sulit untuk menurunkan jumlah belanja pegawai tersebut.

Namun, hal ini seharusnya tidak menjadi penghalang untuk meningkatkan alokasi anggaran belanja modal. Pemerintah daerah dapat menjadikan hal ini sebagai pemicu untuk menghasilkan PAD yang lebih besar agar belanja rutin dapat terpenuhi dan belanja modal juga dapat mengalami peningkatan. Apalagi jika Rancangan Undang-Undang Aparatur Sipil Negara (RUU ASN) yang direncanakan akan disahkan pada Januari 2014 sudah final dan fix ditetapkan sebagai Undang-Undang Aparatur Sipil Negara yang didalamnya mengatur mekanisme baru dalam sistem kepegawaian di pemerintahan, maka masalah belanja pegawai ini tidak akan menjadi alasan sedikitnya belanja modal yang dilakukan oleh pemerintah daerah.

Salah satu poin penting dalam Rancangan Undang - Undang Aparatur Sipil Negara adalah dalam penerapan sistem pembiayaan gaji pegawai. Gaji pegawai aparatur sipil negara (pegawai asn) dalam RUU ASN pasal 75 paragraf 8 tentang penggajian :

1. Pemerintah wajib membayar gaji yang adil dan layak kepada PNS sesuai dengan beban pekerjaan dan tanggung jawab PNS.

2. Gaji sebagaimana dimaksud pada ayat (1) harus memacu produktivitas dan menjamin kesejahteraan PNS.

3. Gaji sebagaiman dimaksud pada ayat (1) dibebankan pada Anggaran Pendapatan dan Belanja Negara

Pembiayaan gaji pegawai DPR dibebankan pada APBN baik ASN di pusat maupun daerah sedangkan pegawai pemerintah dibebankan pada APBN bagi ASN di pusat dan dibebankan pada APBD bagi ASN di daerah. Khusus Jabatan Eselon Senior ((JES) (Eselon I dan II (pusat dan daerah)) gaji pokok dan tunjangan dibebankan pada APBN. Sementara UU tentang Keuangan Negara belum diubah maka gaji tetap dibayarkan oleh instansi/daerah masing-masing.

Pada Kabupaten/Kota di Jawa Barat, belanja modal yang notabene merupakan belanja produktif, masih memiliki proporsi yang relatif kecil dan hanya mencapai $20 \%$ dari total anggaran belanja daerah. Hal ini dapat ditunjukkan oleh tabel berikut :

Tabel 1

Alokasi Belanja Modal (rata-rata) pada Kabupaten/Kota Provinsi Jawa Barat (dalam jutaan rupiah)

\begin{tabular}{|c|c|c|c|}
\hline Tahun & $\begin{array}{c}\text { Belanja } \\
\text { Modal }\end{array}$ & $\begin{array}{c}\text { Total } \\
\text { Belanja }\end{array}$ & $\begin{array}{c}\text { Persentase } \\
\text { B.Modal/Total } \\
\text { Belanja }\end{array}$ \\
\hline 2008 & 196.015 & 1.047 .007 & 19 \\
\hline 2009 & 201.221 & 1.153 .990 & 17 \\
\hline 2010 & 187.642 & 1.256 .965 & 15 \\
\hline 2011 & 233.206 & 1.538 .188 & 15 \\
\hline 2012 & 367.170 & 1.763 .052 & 21 \\
\hline
\end{tabular}

Sumber : Hasil audit BPK, (data diolah)

Dari tahun 2008 hingga tahun 2010, persentase belanja modal terhadap total belanja pemerintah daerah (pemda) terus menurun. Pada tahun 2010 ke 2011 menunjukan persentase yang sama, yaitu $15 \%$ yang merupakan persentase belanja modal terkecil selama 4 tahun tersebut. Walaupun pada tahun 2012 mengalami kenaikan persentase menjadi $21 \%$, namun jumlahnya masih tergolong kecil.

Rata-rata belanja modal secara keseluruhan belanja daerah adalah $20,83 \%$, dengan rincian 9 pemda telah melakukan belanja modal diatas rata-rata dan sisanya sebanyak 17 pemda melakukan belanja daerah dibawah ratarata. Sebanyak 65,39\% pemda di Jawa Barat masih sedikit sekali mengalokasikan keuangan daerahnya pada belanja modal dari total belanja daerahnya.

Sebenarnya tidak ada ukuran yang mengharuskan besarnya belanja 
modal. Alokasi belanja modal disesuaikan dengan kebutuhan daerah akan sarana dan prasarana baik untuk kelancaran tugas pemerintahan maupun untuk fasilitas publik (Halim dan Abdullah, 2006:19).

Akan tetapi melihat keadaan seperti itu, dapat menimbulkan indikasi bahwa pemda lebih banyak mengalokasikan belanjanya pada sektorsektor yang kurang diperlukan dan lebih banyak digunakan untuk belanja rutin yang kurang produktif dibandingkan untuk meningkatkan pelayanan publik, sebab dari $100 \%$ belanja daerah rata-rata hanya $20,83 \%$ yang digunakan untuk belanja modal dalam rangka pengadaan aset untuk investasi yang bertujuan untuk meningkatkan pelayanan publik.

\section{Kerangka Pemikiran}

Otonomi daerah adalah hak, wewenang, dan kewajiban daerah otonom untuk mengatur dan mengurus sendiri urusan pemerintah dan kepentingan masyarakat setempat sesuai dengan peraturan perundang-undangan. Dengan kata lain, daerah diberi kewenangan yang luas dalam mengolah sumber daya potensial yang dimiliki untuk menghasilkan pendapatan yang akan digunakan sebagai sumber pembiayaan kegiatan operasional daerah dan sumber pembiayaan pembangunan dalam upaya meningkatkan kualitas pelayanan publik di daerah tersebut. Otonomi daerah ini diharapkan dapat meningkatkan kemandirian daerah dalam pengelolaan segala sumber daya daerah dengan mengutamakan kepentingan publik.

Anggaran Pendapatan dan Belanja Daerah (APBD) adalah rencana keuangan tahunan pemerintah daerah yang disetujui oleh Dewan Perwakilan Rakyat Daerah. APBD merupakan wujud pengelolaan keuangan daerah yang ditetapkan setiap tahun dengan Peraturan Daerah. Di dalam APBD ini terkandung banyak kepentingan publik yang menjadikan APBD ini sebagai alat yang penting dalam pengelolaan keuangan daerah. APBD pada hakekatnya mencerminkan bagaimana pemerintah daerah mengelola keuangan daerahnya.

Pemanfaatan anggaran belanja seharusnya dialokasikan untuk hal-hal produktif, misalnya untuk pembangunan. Penerimaan pemerintah daerah seharusnya dialokasikan untuk programprogram layanan publik. Pengalokasian belanja modal diharapkan dapat meningkatkan pelayanan pada masyarakat sehingga masyarakat menjadi produktif dan nantinya dapat meningkatkan kembali penerimaan daerah.

Fakta yang terjadi saat ini adalah pemerintah daerah lebih banyak mengalokasikan pendapatan yang diperoleh untuk membiayai belanja rutin atau belanja operasi daripada belanja modal. Padahal seperti yang telah dijelaskan sebelumnya, belanja modal diharapkan akan menambah daya tarik investor untuk berinvestasi di daerah tersebut, menambah pendapatan asli daerah yang akhirnya akan mengurangi ketergantungan pemerintah daerah terhadap pemerintah pusat sehingga kemandirian daerah tercapai.

Belanja modal yang dilakukan oleh pemerintah daerah terdiri dari belanja publik dan belanja aparatur, akan tetapi dalam rangka peningkatan pelayanan publik, dari alokasi dana belanja modal yang relatif kecil dari jumlah keseluruhan belanja daerah tersebut, maka akan lebih bijak apabila pemda lebih mengutamakan belanja modal yang bersifat publik.

Mengingat masih lemahnya kemampuan daerah dalam menggali sumber pendapatan yang berasal dari daerahnya sendiri maka penggunaan belanja modal harus difokuskan pada program-program yang secara berkesinambungan dapat mendukung peningkatan, penyempurnaan maupun memperbaiki sarana dan prasarana yang dapat menunjang peningkatan pembangunan, kesejahteraan masyarakat, dan merangsang terciptanya sumber pendapatan baru. Belanja ini dapat berupa pembangunan dan perbaikan pada sektor-sektor yang memang sangat diperlukan daerah atau dengan kata lain pemerintah daerah harus melakukan skala prioritas dalam 
penentuan belanja modal seperti memprioritaskan sektor pendidikan, kesehatan, transportasi yang dapat menstimulus produktivitas perekonomian baik dalam jangka pendek maupun jangka panjang (masa depan), sehingga akhirnya dapat berdampak pada peningkatan pendapatan daerah. Dan jikalau pemda akan melakukan belanja modal bagi aparatur, maka haruslah untuk meningkatkan kinerja dalam rangka pelayanan publik. Atau dengan kata lain, bahwa tujuan akhirnya adalah untuk pelayanan publik.

Faktor keuangan merupakan salah satu faktor yang penting dalam setiap kegiatan pemerintahan. Dalam rangka menjalankan tugasnya pemerintah daerah harus memiliki sumber keuangan yang cukup memadai, karena untuk melaksanakan pembangunan daerah diperlukan biaya yang tidak sedikit. Pendapatan daerah merupakan sarana pemerintah daerah untuk melaksanakan tujuan maksimalisasi kemakmuran rakyat. Sumber pendapatan daerah dapat dikelompokkan menjadi dua, yaitu pendapatan daerah yang bersumber dari pendapatan asli daerahnya dan pendapatan daerah yang bersumber bukan dari pendapatan asli daerahnya.

Pendapatan Asli Daerah (PAD) merupakan pendapatan daerah yang bersumber dari pendapatan asli daerah. PAD terdiri dari pajak daerah, retribusi daerah, hasil pengelolaan kekayaan daerah yang dipisahkan dan lain-lain pendapatan asli daerah yang sah. "PAD sebenarnya merupakan andalan utama daerah untuk mendukung penyelenggaraan pemerintahan dan pembiayaan pembangunan" (Saragih, 2003 : 55). Semakin besar jumlah uang yang tersedia, semakin banyak pula kemungkinan kegiatan atau pekerjaan yang dapat dilaksanakan.

Abdullah dan Halim pada penelitian tahun 2004 mengemukakan bahwa "pendapatan daerah berpengaruh terhadap belanja modal. Meskipun proporsi PAD maksimal hanya sebesar $10 \%$ dari total pendapatan daerah, kontribusinya terhadap pengalokasian anggaran cukup besar." Pemerintah daerah berusaha meningkatkan
Pendapatan Asli Daerah (PAD) melalui pajak daerah, sebagai sumber pendapatan daerah dalam meningkatkan belanja modal. Kontribusi pajak daerah sangat berpengaruh terhadap pendapatan daerah, hal ini menunjukan bahwa peningkatan Pendapatan Asli Daerah mampu meningkatkan belanja modal. Semakin besar pendapatan daerah yang berhasil dipungut oleh pemerintah daerah maka akan semakin besar pula alokasi belanja modal yang akan dianggarkan oleh pemerintah daerah. Dengan asumsi bahwa pada dasarnya belanja modal yang dikeluarkan oleh pemerintah ditetapkan setelah belanja/pengeluaran daerah yang bersifat rutin sudah tertutupi.

Namun pada penelitian pada tahun 2006, Studi yang dilakukan oleh Abdullah dan Halim (2006:19) menyimpulkan bahwa "PAD (pendapatan sendiri) tidak berasosiasi positif terhadap belanja modal." Temuan yang sama juga pada penelitian yang dilakukan oleh Harianto dan Adi (2007), dan Putro (2011).

PP No. 58 Tahun 2005 menyatakan bahwa APBD disusun sesuai dengan kebutuhan penyelenggaraan pemerintah dan kemampuan daerah dalam menghasilkan pendapatan. Sehingga apabila Pemda ingin meningkatkan belanja modal untuk pelayanan publik dan kesejahteraan masyrakat, maka Pemda harus menggali PAD yang sebesar-besarnya

"Penerimaan daerah dari unsur PAD saja belum mampu memenuhi kebutuhan daerah apalagi dengan penambahan wewenang daerah jelas akan membutuhkan dana tambahan daerah" (Saragih, 2003: 49), sehingga daerah masih tetap membutuhkan bantuan atau dana perimbangan yang berasal dari pusat. Salah satu dana perimbangan yang bersumber dari pemerintah pusat yaitu Dana Alokasi Umum. "Dana perimbangan ini bertujuan untuk mengurangi ketimpangan fiskal antara pemerintah pusat dan pemerintah daerah" (UU No. 33/2004). DAU merupakan sumber pendapatan daerah yang berasal dari pendapatan luar daerah atau dana hibah murni, dimana kewenangan penggunaannya diserahkan kepada Pemerintah Daerah setempat. 


\begin{abstract}
Dana perimbangan keuangan merupakan konsekuensi adanya penyerahan kewenangan pemerintah pusat kepada pemerintah daerah. Dengan demikian, terjadi transfer yang cukup signifikan dalam APBN dari pemerintah pusat ke pemerintah daerah. Pemerintah daerah dapat menggunakan Dana Alokasi Umum untuk memberikan pelayanan kepada publik yang direalisasikan melalui belanja modal.
\end{abstract}

Abdullah dan Halim (2004) menyatakan bahwa "dana transfer jangka panjang berupa DAU berpengaruh terhadap belanja modal dan pengurangan jumlah dana transfer dapat menyebabkan penurunan dalam pengeluaran belanja modal."

Hasil penelitian Harianto dan Adi (2007) semakin memperkuat bukti empiris tersebut. Mereka menemukan bahwa "kemandirian daerah tidak menjadi lebih baik, bahkan yang terjadi adalah sebaliknya yaitu ketergantungan pemerintah daerah terhadap transfer pemerintah pusat (DAU) menjadi semakin tinggi." Hal ini memberikan indikasi kuat bahwa perilaku belanja daerah khususnya belanja modal akan sangat dipengaruhi sumber penerimaan DAU. Berbagai pemaparan diatas dapat disimpulkan semakin tinggi DAU maka alokasi belanja modal juga meningkat. Hal ini disebabkan karena daerah yang memiliki pendapatan daerah berupa DAU yang besar maka belanja modal akan meningkat.

Studi mengenai hubungan antara PAD dan DAU dengan alokasi belanja modal sebenarnya telah banyak dilakukan melalui kajian empiris. DAU juga memiliki hubungan dengan alokasi belanja modal. Holtz-Eakin at al (dalam Harianto dan Adi, 2007) menyatakan bahwa "terdapat keterkaitan sangat erat antara transfer dari pemerintah pusat dengan belanja modal." Kemudian Gamkhar dan Oates (dalam Maimunah, 2006 : 5) menyatakan bahwa "pengurangan jumlah transfer (cut in the federal grants) menyebabkan penurunan dalam pengeluaran daerah." Saragih (2003 : 57) pun mengemukakan bahwa "pengalaman empiris menunjukan bahwa sebagian besar daerah tidak mampu ngandalkan PAD untuk membiayai kebututuhan pengeluarannya, sehingga harus mendapatkan dana dari pusat berupa DAU untuk membiayai pengeluaran daerah."

Penelitian hubungan DAU dengan belanja modal pernah dilakukan oleh Ikin Solikin (2007) dengan hasil bahwa "terdapat hubungan positif yang kuat antara DAU dengan Belanja Modal."

\section{Hipotesis}

Berdasarkan pemaparan kerangka pemikiran di atas, hipotesis dalam penelitian ini yang diajukan adalah "Terdapat Hubungan Positif antara Pendapatan Asli Daerah (PAD) dan Dana Alokasi Umum (DAU) dengan Belanja Modal di Pemerintah Daerah Se-Provinsi Jawa Barat Tahun Anggaran 2012"

\section{Populasi dan Sampel}

Populasi yang digunakan dalam penelitian ini adalah Pemerintah Daerah setingkat Kabupaten/Kota yang ada di Jawa Barat yang mencantumkan laporan realisasi APBD pada tahun 2012. Sampel pada penelitian ini adalah 26 Pemerintah Daerah setingkat Kabupaten/Kota yang ada di Provinsi Jawa Barat pada tahun 2012.

\section{Teknik Pengumpulan Data}

Untuk memperoleh data yang diperlukan dalam penelitian ini, cara yang digunakan adalah studi dokumentasi, dilakukan dengan cara mengumpulkan dokumen-dokumen Laporan Keuangan Pemerintah yang berkaitan dengan data yang diperlukan dalam kegiatan penelitian ini. Data yang digunakan oleh penulis diperoleh dari website resmi Badan Pemeriksa Keuangan RI di http://www.bpk.go.id dan dari Badan Pemeriksaan Keuangan RI Perwakilan Jawa Barat Jl. Moh. Toha No. 164

\section{Teknik Analisi Data dan Pengujian Hipotesis}

Analisis data adalah proses penyederhanaan data dalam bentuk yang lebih mudah dibaca dan diinterpretasikan. Untuk itu, data yang dihimpun dari hasil penelitian di lapangan akan disusun dan dibandingkan dengan data kepustakaan, kemudian dilakukan analisis untuk ditarik kesimpulan. 
Analisis dalam penelitian ini menggunakan statistik parametrik dengan menggunakan model korelasi multiple. Alasan penggunaan analisis ini merujuk pada tujuan penelitian ingin melihat hubungan dari variabel bebas pendapatan asli daerah dan dana alokasi umum dengan variabel terikat belanja modal, dan analisis korelasi multiple adalah teknik yang sesuai dengan tujuan tersebut.

\section{Pengujian Hipotesis}

Sebelum dilakukan pengujian hipotesis perlu dilakukan analisis korelasi multipel untuk menentukan koefisien korelasi antar variabel.

Koefisien korelasi multipel $\left(\mathrm{R}_{\mathrm{y} .12}\right)$ merupakan koefisien korelasi secara simultan antara pendapatan asli daerah dan dana alokasi umum dengan belanja modal. Nilai $r_{12}, r_{y 1}$ dan $r_{y 2}$ berturut-turut menunjukkan koefisien korelasi antara pendapatan asli daerah dan dana alokasi umum, pendapatan asli daerah dan belanja modal, serta dana alokasi umum dan belanja modal.

Nilai $r_{12}$ tersebut ditentukan dengan menggunakan analisis korelasi Pearson Product Moment. Selain kedua koefisien korelasi tersebut perlu ditetapkan juga koefisien korelasi parsial yang menunjukkan keeratan hubungan antara variabel $Y$ dengan sebagian variabel bebas apabila sebagian lagi dianggap tetap (Sudjana, 2004:265).

Rumusan hipotesis statistik yang digunakan dalam penelitian ini diantanya:

a. Rumusan hipotesis statistik untuk menentukan korelasi parsial antara pendapatan asli daerah dan belanja modal.

$\begin{array}{lll}\mathrm{H}_{0_{1}} & & \text { Tidak terdapat } \\ : \rho_{1} & & \text { hubungan Pendapatan } \\ =0 & \text { Asli Daerah dengan } \\ & \text { belanja modal di } \\ & \text { Pemerintah Daerah Se- } \\ & \text { Provinsi Jawa Barat } \\ & \text { tahun anggaran 2012 } \\ \mathrm{H}_{1_{1}} & \text { Terdapat } & \text { hubungan } \\ : \rho_{1} & \text { positif } & \text { Pentara } \\ \neq 0 & & \text { Daerah dengan belanja }\end{array}$

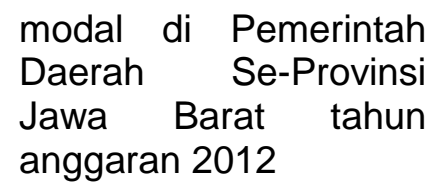

b. Rumusan hipotesis statistik untuk menentukan korelasi parsial antara dana alokasi umum dan belanja modal.

$\begin{array}{llr}\mathrm{H}_{\mathrm{O}_{2}} & \text { Tidak } & \text { terdapat } \\ : \rho_{2} & \text { hubungan } & \text { Dana }\end{array}$

$\begin{array}{ll}: \rho_{2} & \text { Alokasi Umum dengan } \\ =0 & \end{array}$ belanja modal di Pemerintah Daerah SeProvinsi Jawa Barat tahun anggaran 2012

$\mathrm{H}_{1_{2}} \quad$ Terdapat hubungan

$: \rho_{2} \quad$ positif antara Dana

$\neq 0 \quad$ Alokasi Umum dengan belanja modal di Pemerintah Daerah SeProvinsi Jawa Barat tahun anggaran 2012

c. Rumusan hipotesis statistik untuk menentukan korelasi antara Pendapatan Asli Daerah dan Dana Alokasi Umum dengan belanja modal.

$$
\begin{aligned}
& \mathrm{H}_{0_{3}}: \mathrm{R} \text { Tidak terdapat } \\
& =0 \text { hubungan Pendapatan } \\
& \text { Asli Daerah dan Dana } \\
& \text { Alokasi Umum dengan } \\
& \text { terhadap belanja modal } \\
& \text { di Pemerintah Daerah } \\
& \text { Se-Provinsi Jawa Barat } \\
& \text { tahun anggaran } 2012 \\
& \mathrm{H}_{1_{3}} \text { : } \mathrm{R} \text { Terdapat hubungan } \\
& \neq 0 \text { positif antara } \\
& \text { Pendapatan Asli }
\end{aligned}
$$

Uji t digunakan untuk menguji hipotesis secara parsial. Rumus yang digunakan adalah dengan rumus thitung. Setelah diperoleh thitung, selanjutnya bandingkan dengan $t_{\text {tabel. }}$. Taraf signifikansi yang digunakan adalah 0,05 dengan derajat kebebasan, $\mathrm{dk}=\mathrm{n}-3$. Adapun kaidah kriteria pengujiannya adalah:

Jika $-t_{\text {tabel }} \leq t_{\text {hitung }}<t_{\text {tabel }}$ maka $\mathrm{H}_{0}$ diterima dan $\mathrm{H}_{1}$ ditolak

Jika $t_{\text {hitung }}>t_{\text {tabel }}$ atau $-t_{\text {nitung }} \leq-t_{\text {tabel }}$ maka $\mathrm{H}_{0}$ ditolak dan $\mathrm{H}_{1}$ diterima 
Apabila $t_{\text {hitung }}>t_{\text {tabel }}$ atau $-t_{\text {hitung }} \leq-$ $t_{\text {tabel }}$ maka koefisien korelasi parsial tersebut menunjukkan adanya pengaruh secara parsial antara sebagian variabel bebas dan variabel terikat. Begitu juga sebaliknya, apabila $-t_{\text {tabel }} \leq t_{\text {hitung }}<t_{\text {tabel }}$ maka koefisien korelasi parsial tersebut tidak menunjukkan adanya pengaruh secara parsial antara sebagian variabel bebas dan variabel terikat.

Untuk menguji hipotesis berkorelasi multipel, yaitu pendapatan asli daerah dan dana alokasi umum berpengaruh terhadap belanja modal dengan menggunakan rumus $F_{\text {hitung. }}$ Setelah diperoleh $F_{\text {hitung, selanjutnya }}$ bandingkan dengan $F_{\text {tabel. }}$ Taraf signifikansi yang digunakan adalah 0,05 dengan derajat kebebasan, dk Pembilang $=\mathrm{k}$, dk penyebut $=\mathrm{n}-\mathrm{k}-1$. Adapun kaidah kriteria pengujiannya adalah:

Jika $F_{\text {hitung }}>F_{\text {tabel }}$ atau $-F_{\text {hitung }}<-$ $F_{\text {tabel }}$, maka $\mathrm{H}_{1_{3}}$ diterima dan $\mathrm{H}_{0_{3}}$ ditolak Jika $F_{\text {hitung }} \leq F_{\text {tabel }}$ atau $-F_{\text {hitung }} \geq$ $F_{\text {tabel }}$, maka $\mathrm{H}_{1_{3}}$ ditolak dan $\mathrm{H}_{0_{3}}$ diterima

\section{Hasil Penelitian}

\section{Hubungan Pendapatan Asli Daerah dengan Belanja Modal pada Pemerintah Daerah Se-Provinsi Jawa Barat Tahun Anggaran 2012}

Berdasarkan hasil pengujian yang dilakukan, secara parsial, hubungan antara Pendapatan Asli Daerah dengan Belanja Modal pada pemerintah daerah se-Provinsi Jawa Barat tahun anggaran 2012 memiliki nilai sebesar 0,9013 yang berarti bahwa pendapatan asli daerah dengan belanja modal memiliki hubungan yang sangat kuat/sangat erat. Dengan membandingkan thitung dengan $t_{\text {tabel }}$, dimana variabel independen PAD memiliki $t_{\text {hitung }}$ sebesar 9,9809 dengan $t_{\text {tabel, }}$, sebesar 2,069, maka thitung $>t_{\text {tabel }}$ maka $\mathrm{H}_{0_{1}}$ ditolak dan $\mathrm{H}_{1_{1}}$ diterima. Maka berdasarkan pengujian pada penelitian ini terbukti bahwa terdapat hubungan positif yang sangat kuat/sangat erat antara pendapatan asli daerah dengan belanja modal pada pemerintah daerah seProvinsi Jawa Barat tahun anggaran 2012.

Hasil penelitian ini serupa dengan hasil penelitian Ikin Solikin (2007) dan Putro (2011) yang menyatakan bahwa terdapat hubungan positif dan signifikan antara PAD dengan belanja modal. Secara teoritis pendapatan sendiri merupakan salah satu sumber pendapatan yang dapat digunakan untuk membiayai pelayanan publik. Namun, untuk kasus pemerintah daerah di Indonesia, persentase tersebut hanya sekitar $5-7 \%$ dari total penerimaan pemerintah daerah.

Daerah yang ditunjang dengan sarana dan prasarana memadai akan berpengaruh pada tingkat produktivitas masyarakatnya dan akan menarik investor untuk menanamkan modalnya pada daerah tersebut yang pada akhirnya akan menambah pendapatan asli daerah. Peningkatan PAD diharapkan mampu memberikan efek yang signifikan terhadap pengalokasian anggaran belanja modal oleh pemerintah. "Peningkatan investasi modal (belanja modal) diharapkan mampu meningkatkan kualitas layanan publik dan pada gilirannya mampu meningkatkan tingkat partisipasi (kontribusi) publik terhadap pembangunan yang tercermin dari adanya peningkatan PAD" (Mardiasmo, 2004). Dengan kata lain, hasil perhitungan PAD dan belanja modal memiliki hubungan positif yang sangat tinggi memiliki makna, pembangunan berbagai fasilitas sektor publik (belanja modal) akan berujung pada peningkatan pendapatan daerah. Pelaksanaan desentralisasi membuat pembangunan menjadi prioritas utama pemerintah daerah untuk menunjang peningkatan PAD.

\section{Hubungan Dana Alokasi Umum dengan Belanja Modal pada Pemerintah Daerah Se-Provinsi Jawa Barat Tahun Anggaran 2012}

Berdasarkan hasil pengujian yang dilakukan, secara parsial, hubungan antara Dana Alokasi Umum dengan Belanja Modal pada pemerintah daerah se-Provinsi Jawa Barat tahun anggaran 2012 memiliki nilai sebesar 0,5898 yang berarti bahwa dana alokasi umum dengan belanja modal memiliki hubungan yang cukup/sedang. Dengan membandingkan $t_{\text {hitung }}$ dengan tabel, dimana variabel independen DAU memiliki thitung sebesar 3,5029 dengan tabel, sebesar 2,069, maka 
$t_{\text {hitung }}>t_{\text {tabel }}$ maka $\mathrm{H}_{0_{2}}$ ditolak dan $\mathrm{H}_{1_{2}}$ diterima. Maka berdasarkan pengujian pada penelitian ini terbukti bahwa terdapat hubungan positif yang cukup/sedang antara dana alokasi umum dengan belanja modal pada pemerintah daerah seProvinsi Jawa Barat tahun anggaran 2012. Hasil penelitian ini hampir serupa dengan penelitian Ikin Solikin (2007) dan Putro (2011) yang menyatakan bahwa terdapat hubungan positif dan signifikan antara DAU dengan belanja modal. Hal ini mengindikasikan pula bahwa terdapat hubungan antara pemberian dana transfer dari pemerintah pusat yaitu DAU, dengan aloksi pengeluaran daerah melalui aloksi belanja modal.

Holtz-Eakin et al (dalam Hariyanto dan Adi, 2007) menyatakan bahwa terdapat keterkaitan sangat erat antara transfer dari pemerintah pusat dengan belanja modal. Kemudian Gamkhar dan Oates (dalam Maimunah, 2006:5) juga menyatakan bahwa pengurangan jumlah transfer (cut in the federal grants) menyebabkan penurunan dalam pengeluaran daerah. Hal ini mengindikasi bahwa semakin tinggi DAU maka pengeluaran pemerintah atas belanja modal pun akan semakin tinggi.

\section{Hubungan Pendapatan Asli Daerah dan Dana Alokasi Umum dengan Belanja Modal pada Pemerintah Daerah Se- Provinsi Jawa Barat Tahun Anggaran 2012}

Berdasarkan hasil pengujian yang dilakukan, secara simultan hubungan antara Pendapatan Asli Daerah dan Dana Alokasi dengan Belanja Modal pada pemerintah daerah se-Provinsi Jawa Barat tahun anggaran 2012 memiliki nilai sebesar 0,9413 yang berarti bahwa pendapatan asli daerah dan dana alokasi umum dengan belanja modal memiliki hubungan yang sangat kuat/sangat erat. Dengan membandingkan $F_{\text {hitung }}$ dengan $F_{\text {tabel, }}$ dimana diperoleh nilai $F_{\text {hitung }}$ sebesar 89,3464 sedangkan $F_{\text {tabel }}$ pada tingkat kepercayaan $95 \%(\alpha=0,05)$ adalah 3,42. Hal ini berarti bahwa nilai $F_{\text {hitung }}>F_{\text {tabel }}$ $(89,3464>4,28)$. Maka berdasarkan pengujian pada penelitian ini terbukti bahwa terdapat hubungan positif yang sangat kuat/sangat erat antara variabel
Pendapatan Asli Daerah dan Dana Alokasi Umum dengan belanja modal pada pemerintah daerah se-Provinsi Jawa Barat tahun anggaran 2012.

PAD dan DAU sangat berperan terhadap pembiayaan belanja daerah. Akan tetapi pemerintah daerah belum mampu mengandalkan PAD sepenuhnya untuk membiayai desentralisasi. Begitu pula dengan pemerintah pusat yang tidak mau sepenuhnya memberikan DAU karena akan menambah ketergantungan daerah kepada pusat. PAD adalah "kas bebas" yang boleh dialokasikan untuk belanja apa saja, tergantung kebijakan Pemda, kecuali untuk belanja gaji dan tunjangan pegawai sebab sudah ditutupi dengan DAU. PAD menjadi bagian dari perhitungan DAU, sebab DAU adalah alokasi dari APBN untuk menutupi kesenjangan fiskal. Kesenjangan fiskal diukur dari selisih antara kebutuhan daerah dengan kemampuan daerah. PAD menjadi bagian dari kemapuan keuangan daerah itu. Jadi, kalau PAD naik (kemampuan keuangan daerah naik), seharusnya DAUnya turun.

$$
\text { Apabila daerah memiliki }
$$

pendapatan besar maka belanja pun dapat ikut ditingkatkan. Dalam penelitian ini menunjukan adanya hubungan sangat kuat antara PAD dengan DAU atas hubungannya dengan belanja modal. Hal tersebut menunjukan bahwa adanya hubungan yang sangat kuat antara pendapatan dan belanja modal. Pemerintah daerah Se-Provinsi Jawa Barat diharapkan aktif dalam menggali potensi - potensi daerah yang dapat meningkatkan PAD yang bersumber dari penerapan belanja modal, sehingga diharapkan ketergantungan akan DAU dapat berkurang dan pelayanan publik tetap terpenuhi dengan maksimal.

\section{Kesimpulan}

Berdasarkan penelitian yang telah dilakukan pada pemerintah daerah SeProvinsi Jawa Barat tahun anggaran 2012, dapat disimpulkan bahwa :
1. Kabupaten Bogor memiliki PAD tertinggi yaitu sebesar Rp 1.048.230.704.202,00 dan PAD terendah adalah Kota Banjar yaitu $\mathrm{Rp}$ 
54.684.690.641,00. Total DAU tertinggi diterima Kabupaten Bogor dengan jumlah DAU Rp. 1.672.614.142.000,00 dan daerah dengan DAU terendah adalah Kota Banjar dengan jumlah DAU sebesar Rp 281.851.254.000,00. Total belanja modal seluruh populasi sebesar $\mathrm{Rp}$ 9.546.420.767.261,00 dengan ratarata $\quad \mathrm{Rp} \quad 367.170 .029 .510,04$. Kabupaten Bogor adalah Pemda dengan total belanja modal tertinggi sebesar Rp. 1.035.467.433.416,00. Sedangkan yang terendah adalah Kota Sukabumi yakni sebesar $\mathrm{Rp}$ 61.371.774.294,00.

2. Hubungan PAD dengan belanja modal pada penelitian ini menunjukan bahwa terdapat hubungan positif yang sangat kuat antara PAD dengan belanja modal. Hal ini dapat diartikan bahwa pembangunan berbagai fasilitas sektor publik (belanja modal) akan berujung pada peningkatan pendapatan daerah. Pelaksanaan desentralisasi membuat pembangunan menjadi prioritas utama pemerintah daerah untuk menunjang peningkatan PAD.

3. Hubungan DAU dengan belanja modal pada penelitian ini menunjukan hasil bahwa terdapat hubungan positif yang sedang antara DAU dengan belanja modal. Hal ini dapat diartikan bahwa semakin tinggi DAU maka pengeluaran pemerintah atas belanja modal pun akan semakin tinggi.

4. Berdasarkan penelitian mengenai hubungan PAD dan DAU dengan belanja modal dapat diketahui bahwa terdapat hubungan positif yang sangat kuat antara PAD dan DAU dengan belanja modal pada pemerintah daerah se-Provinsi Jawa Barat tahun anggaran 2012.

\section{Saran}

1. Pemerintah daerah diharapkan lebih memprioritaskan anggaran untuk kepentingan publik dengan cara meningkatkan alokasi belanja modal untuk kepentingan publik. Sebab dengan meningkatnya alokasi belanja modal akan semakin meningkatkan investasi yang nantinya akan meningkatkan pendapatan daerah akibat dari semakin produktivnya masyarakat.

2. Tingginya PAD yang dihasilkan adalah tolok ukur kemandirian daerah. Semakin tingginya PAD tersebut maka akan semakin mengurangi ketergantungan pemerintah daerah terhadap pemerintah pusat. Hal ini menunjukan tercapainya salah satu tujuan dari otonomi daerah. Salah satu cara meningkatkan PAD dapat dilakukan melalui ekstensifikasi dan intensifikasi pajak.

3. Bagi peneliti selanjutnya, hasil penelitian ini dapat dijadikan acuan untuk melakukan penelitian lanjutan dengan mempertimbangkan faktorfaktor lain yang mempengaruhi semua variabel, salah satunya adalah perbedaan sistem setelah disahkannya RUU ASN, serta dengan menambahkan sampel yang digunakan dan memperluas periode pengamatan.

\section{DAFTAR PUSTAKA}

\section{Sumber Buku :}

Arikunto,S. (2002). Prosedur Penelitian. Jakarta: Rineka Cipta

Ghozali, I. (2012). Statistik Multivariat SPSS. Penerbit BP Universitas Diponegoro.

Halim, A. (2002). Akuntansi Keuangan Daerah. Jakarta : Salemba Empat . (2004). Seri Bunga Rampai Manajmenen Keuangan daerah Pengelolaan Keuangan Daerah. Yogyakarta: UPP AMP YKPN

\begin{tabular}{ccc} 
& (2007). & Pengelolaan \\
\hline Keuangan Daerah. & Yogyakarta: \\
UPP STIM YKPN &
\end{tabular}

Hasan, I. (2004). Analisis Data Penelitian dan Statistik. Jakarta: Bumi Aksara

Mardiasmo (2004). Akuntansi Sektor Publik. Yogyakarta : Andi Yogyakarta

Mahmudi. (2006). Analisis Laporan Keuangan Pemerintah Daerah. Yogyakarta: Andi 
Riduwan, dan Akdon. (2010). Rumus dan Data dalam Analisis Statistika. Bandung : Alfabeta.

Saragih, J.P. (2003). Desentralisasi Fiskal dan Keuangan Daerah dalam Otonomi. Bogor: Penerbit Ghalia Indonesia.

Sudjana (2003). Teknik Analisis Regresi dan Korelasi. Bandung : Penerbit PT. Tarsito Bandung

Sudjana (2005). Metoda Satistika. Bandung : Penerbit PT. Tarsito Bandung

Sugiyono. (2012). Metode Penelitian Bisnis. Bandung Alfabeta

Ulum.I. (2008). Akuntansi Sektor Publik. Malang: UMM Press

\section{Peraturan Pemerintah dan Perundang-} undangan :

Peraturan Mentri Dalam Negeri No. 13 Tahun 2006 tentang Pedoman Pengelolaan Keuangan Daerah.

Peraturan Pemerintah Republik Indonesia No. 58 Tahun 2005 tentang Pengelolaan Keuangan Daerah.

Peraturan Pemerintah Republik Indonesia No. 55 tahun 2005 tentang Dana Perimbangan.

Peraturan Pemerintah Republik Indonesia No. 71 Tahun 2010 tentang Standar Akuntansi Pemerintah Undang-Undang Republik Indonesia Nomor 17 tahun 2003 tentang Keuangan Negara, Departemen Komunikasi dan Informatika. Jakarta.

Undang-Undang

Republik Indonesia Nomor 32 Tahun 2004 tentang Pemerintah Daerah. Departemen Komunikasi dan Informatika. Jakarta.

Undang-Undang

Republik Indonesia Nomor 33 Tahun 2004 tentang Perimbangan Keuangan antara Pemerintah Pusat dan Pemerintah Daerah, Departemen Komunikasi dan Informatika. Jakarta.

Undang-Undang

Republik Indonesia Nomor 56 Tahun 2005 tentang Sistem Informasi Keuangan Daerah. Departemen Komunikasi dan Informatika. Jakarta.
Undang-Undang

Republik Indonesia Nomor 56 Tahun 2005 tentang Sistem Informasi Keuangan Daerah. Departemen Komunikasi dan Informatika. Jakarta.

\section{Sumber Jurnal :}

Abdullah, S., dan Halim A. (2004). "Pengaruh Dana Alokasi Umum (DAU) dan Pendapatan Asli Daerah (PAD) terhadap Belanja Pemerintah Daerah : Studi Kasus Kabupaten dan Kota di Jawa dan Bali". Simposium Nasional Akuntansi VI, hal. 1140-1159.

Abdullah, S., dan Halim A. (2006). "Studi atas Belanja Modal pada Anggaran Pemerintah Daerah dalam Hubungannya dengan Belanja Pemeliharaan dan Sumber Pendapatan'. Jurnal Akuntansi Pemerintah. Vol.2No.2 Hal 17-32 [online]. Tersedia http://syukriy.wordpress.com/2008/ 10/20/studi-atas-belania-modalpada-anggaran-pemerintahdaerah-dalam-hubungannyadengan-belanja-pemeliharaan-dansumber-pendapatan/

Adi, P.H. (2006). "Hubungan Antara Pertumbuhan Ekonomi Daerah, Belanja Pembangunan dan Pendapatan Asli Daerah". Simposium Nasional Akuntansi IX. Darwanto, dan Yustikasari, Y. (2007). "Pengaruh Pertumbuhan Ekonomi, Pendapatan Asli Daerah dan Dana Alokasi Umum terhadap Pengalokasian Anggaran Belanja Modal". Simposium Nasional Akuntansi. Jurnal Akuntansi dan Keuangan Sektor Publik, Vol 08 No. 01. February 2007. BPFE UGM. Yogyakarta

Halim, A., dan Abdullah, S. (2006). Hubungan dan Masalah Keagenan di Pemerintahan Daerah: Sebuah Peluang Penelitian Anggaran dan Akuntansi. Jurnal Akuntansi Pemerintah 2(1): 53-64. 
Harianto, D., dan Adi, P.H.(2007). "Hubungan Antara Dana Alokasi Umum, Belanja Modal, Pendapatan Asli Daerah dan Pendapatan per Kapita". Simposium Nasional Akuntansi X.

Maimunah, M. (2006). Flypaper Effect Pada Dana Alokasi Umum (DAU) dan Pendapatan Asli Daerah (PAD) terhadap Belanja Daerah pada Kabupaten/Kota di Pulau Sumatera. Simposium Nasional Akuntansi IX.

Solikin, Ikin. 2007. Hubungan pendapatan asli daerah dan dana alokasi umum dengan belanja modal di jawa barat. 18 Desember 2013. http://file.upi.edu/Direktori/FPEB/P RODI.AKUNTANSI/196510122001 $121-$

$\underline{\text { IKIN SOLIKIN/Jurnal PAD.pdf }}$

Sumber Internet :

(2013). Antara.

Pengendara di Garut Keluhkan Jalanan Rusak. http://www.antarajawabarat.com/lih at/berita/30221/pengendara-digarut-keluhkan-jalanan-rusak

\section{(2013). Republika.} Jalur Pantura, Cikampek-Cirebon Masih Banyak Jalan Rusak http://www.republika.co.id/berita/na sional/umum/13/06/19/momcdvjalur-pantura-cikampekcirebonmasih-banyak-jalan-rusak (2013). Tribun News.

Pejabat Biarkan Jalanan Rusak Parah di Bogor, Warga ancam gabung ke Tangerang Selatan. http://www.tribunnews.com/tribunn ers/2013/10/18/pejabat-biarkanjalanan-rusak-parah-di-bogorwarga-ancam-gabung-ketangerang-selatan

Editorial Media Indonesia. Menggenjot Belanja Modal. Edisi 25 Agustus 2008. [online]. Tersedia http://www.media-indonesia.com Html [18 Oktober 2013]

Website BPK RI www.bpk.go.id

Website Departemen Keuangan RI http://www.djpk.depkeu.go.id
Website

Tribun

Jabar 